\title{
Seropositive rheumatoid arthritis associated with decreased diffusion capacity of the lung
}

\author{
G. SCHERNTHANER, O. SCHERAK, G. KOLARZ, AND F. KUMMER \\ From II. Medical Clinic, University of Vienna, Austria
}

\begin{abstract}
Schernthaner, G., Scherak, O., Kolarz, G., and Kummer, F. (1976). Annals of the Rheumatic Diseases, 35, 258-262. Seropositive rheumatoid arthritis associated with decreased diffusion capacity of the lung. Sixty-two patients with classical or definite rheumatoid arthritis were subjected to lung function analysis. The various parameters-spirography, plethysmography, blood gas analysis, measurement of lung compliance, and diffusion capacity - were correlated with duration and stage of disease, and with rheumatoid factor titres.

A statistically significant correlation was found to exist between Rose-Waaler titre and specific diffusion capacity. Similar results between Rose-Waaler titre and lung compliance, however, were not statistically significant.
\end{abstract}

Involvement of the lungs in rheumatoid arthritis (RA) has been found in varying degrees depending on the method of investigation. Lung changes in RA have been reported by several authors. The prevalence depends on the method of investigation, namely, whether autopsy (Aronoff, Bywaters, and Fearnley, 1955; Talbott and Calkins, 1964), $x$-ray (Horler and Thompson, 1959; Georg, 1961; Sievers, Hurri, and Perttala, 1964; Brannan and others, 1964; Patterson, Harville, and Pierce, 1965; Pierce, 1968; Walker and Wright, 1969; Vignon, 1972; Hofner, LobenweinWeinegg, and Thumb, 1974), or lung function (Newcomer and others, 1964; Huang and Lyons, 1966; Loddenkemper, Bach, and Carton, 1970; Popper, Bogdonoff, and Hughes, 1972; Frank and others, 1973; Laitinen, Salorinne, and Poppius, 1973; Morere, Stain, and Nouvet, 1973; Davidson, Brooks, and Bacon, 1974; Börngen, 1975) was applied.

Rheumatoid factors have also been shown frequently in idiopathic interstitial fibrosis of the lung (Tomasi, Fudenberg, and Fiuby, 1962; TurnerWarwick and Doniach, 1965; Ward and Stalker, 1965), in which case morphological changes often appear to be very similar to those seen in rheumatoid lung disease. Hence, several authors have looked for a dependency of lung function changes on seropositive arthritis and found a higher frequency of overall lung function disturbance in seropositive RA (Frank and others, 1973; Morere and others, 1973). The question arose whether these changes were due to a genera deterioration of the arthritic patient, or to the influence of the immunological process itself on certain well-defined lung function parameters.

\section{Patients}

Sixty-two patients (55 women, 7 men) with classical or definite RA were submitted to lung function analysis. Classification was made according to Steinbrocker, Traeger, and Batterman (1949). The following clinicalserological data were examined: determination of rheumatoid factors (Rose-Waaler titre), sedimentation rate (Westergren), electrophoresis, antinuclear antibodies, LE cells, peripheral blood count, chest $x$-ray, and electrocardiogram. Patients with heart disease or considerable anaemia (women $\leqslant \mathrm{Hb} 9 \mathrm{~g} / \mathrm{dl}$; men $\leqslant 10 \mathrm{~g} / \mathrm{dl}$ ) were excluded. 9 patients $(14.5 \%)$ had smoked approximately 15 cigarettes daily during the past 20 years. No patient had any histological or clinical evidence of dust exposure.

In Table IA and B the 62 patients are classified according $\sigma$ to clinical data (age, duration of disease, Steinbrocker- N staging) and rheumatoid factor; these parameters were $N$ correlated with lung function data.

\section{Lung function data}

(1) Lung volumes (vital capacity, VC; functional residual capacity, FRC; total lung capacity, TLC; residual volume, $\mathrm{RV}$ ).

(2) Ventilatory capacity $\left(\mathrm{FEV}_{1}\right.$, maximal breathing capacity, MBC). 
Table IA Stage of disease (Steinbrocker), Rose-Waaler titre, duration of disease, and patient's age

\begin{tabular}{|c|c|c|c|c|c|c|}
\hline & \multicolumn{4}{|c|}{ Stage of disease (Steinbrocker) } & \multirow[b]{2}{*}{$\begin{array}{l}\text { Total } \\
\text { no. }\end{array}$} & \multirow[b]{2}{*}{$\begin{array}{l}\text { Age (years) } \\
(\text { mean } \pm S D)\end{array}$} \\
\hline & 1 & 2 & 3 & 4 & & \\
\hline \multicolumn{7}{|c|}{ Age (years) } \\
\hline $\begin{array}{l}\text { Mean } \\
\text { SD } \\
\text { n }\end{array}$ & $\begin{array}{l}54 \cdot 05 \\
18 \cdot 48 \\
20\end{array}$ & $\begin{array}{l}58 \cdot 53 \\
13 \cdot 31 \\
17\end{array}$ & $\begin{array}{l}59 \cdot 83 \\
12 \cdot 25 \\
18\end{array}$ & $\begin{array}{l}58 \cdot 14 \\
8 \cdot 00 \\
7\end{array}$ & 62 & $\begin{array}{l}57 \cdot 46 \\
14 \cdot 43\end{array}$ \\
\hline \multicolumn{7}{|c|}{ Rose-Waaler titre } \\
\hline $\begin{array}{l}\geqq 1: 64 \\
<1: 64\end{array}$ & $\begin{array}{r}7 \\
13\end{array}$ & $\begin{array}{r}10 \\
7\end{array}$ & $\begin{array}{r}13 \\
5\end{array}$ & $\begin{array}{l}2 \\
5\end{array}$ & $\begin{array}{l}32 \\
30\end{array}$ & $\begin{array}{l}59 \cdot 06 \pm 12 \cdot 39 \\
54 \cdot 63 \pm 17 \cdot 76\end{array}$ \\
\hline \multicolumn{7}{|c|}{$\begin{array}{l}\text { Duration of } \\
\text { disease (years) }\end{array}$} \\
\hline $\begin{array}{l}0-3 \\
4-10 \\
>10\end{array}$ & $\begin{array}{r}13 \\
5 \\
2\end{array}$ & $\begin{array}{l}3 \\
9 \\
5\end{array}$ & $\begin{array}{r}1 \\
4 \\
13\end{array}$ & $\begin{array}{l}-\overline{1} \\
6\end{array}$ & $\begin{array}{l}17 \\
19 \\
26\end{array}$ & $\begin{array}{l}51 \cdot 64 \pm 17.93 \\
58 \cdot 73 \pm 13 \cdot 55 \\
60.23 \pm 11 \cdot 60\end{array}$ \\
\hline
\end{tabular}

Table IB Groups of patients with increasing RoseWaaler titre, by age and stage of disease

\begin{tabular}{|c|c|c|c|c|}
\hline & \multicolumn{4}{|c|}{ Rose-Waaler titre } \\
\hline & $1: 64$ & $1: 64 / 1: 128$ & $1: 256 / 1: 512$ & $>1: 512$ \\
\hline \multicolumn{5}{|l|}{$\begin{array}{l}\text { Age } \\
\text { (years) }\end{array}$} \\
\hline $\begin{array}{l}\text { Mean } \\
\text { SD } \\
\mathbf{n}\end{array}$ & $\begin{array}{l}54 \cdot 63 \\
17 \cdot 70 \\
30\end{array}$ & $\begin{array}{l}58 \cdot 58 \\
13 \cdot 66 \\
12\end{array}$ & $\begin{array}{l}56 \cdot 16 \\
12 \cdot 95 \\
12\end{array}$ & $\begin{array}{c}64 \cdot 12 \\
8 \cdot 90 \\
8\end{array}$ \\
\hline \multicolumn{5}{|c|}{$\begin{array}{l}\text { Stage of } \\
\text { disease (n) }\end{array}$} \\
\hline $\begin{array}{l}1 \\
2 \\
3 \\
4\end{array}$ & $\begin{array}{r}13 \\
7 \\
5 \\
5\end{array}$ & $\begin{array}{l}3 \\
3 \\
5 \\
1\end{array}$ & $\begin{array}{l}2 \\
3 \\
6 \\
1\end{array}$ & $\begin{array}{r}2 \\
4 \\
2 \\
-\end{array}$ \\
\hline
\end{tabular}

(3) Breathing mechanics (airway resistance, $\mathbf{R}_{\mathrm{aw}}$; static compliance, $\mathrm{C}$; expressed as specific compliance, C/FRC).

(4) Diffusion capacity, $D_{L c o}$; expressed as specific $D_{L c o}$

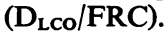

(5) Blood gas analysis $\left(\mathrm{PO}_{2}\right.$, base excess) from arterialized capillary blood.

\section{Methods}

Spirogram at the open circuit system with integration of the flow signal (Siemens/Erlangen); whole body plethysmography by a constant volume type (Siregnost FD 91, Siemens/Erlangen). Compliance was measured by the oesophageal method during a 'quasi-static' manoeuvre (vital capacity, very slow inspiratory and expiratory). Diffusion capacity was measured by the steady state procedure with end-tidal sampling of 'alveolar' COconcentration (Alveodiffusionstest, Jaeger/Würzburg). Blood gases were analysed by the Radiometer-unit/ Copenhagen.
VC and TLC were compared with the expected values of Baldwin, Cournand, and Richards (1948), FEV 1 was expressed in \%VC, FRC and RV in \%TLC, specific compliance was considered normal $>0.055$; lower limit of normal for specific $D_{\text {Lco }}$ was 4.5 units/1 FRC.

Bronchial obstruction was assessed by airway resistance $>3.0$ and/or $\mathrm{FEV}_{1}<60 \% \mathrm{VC}$, as well as by proportional increase of the area of the compliance loop during maximal ventilation.

\section{Results}

Mean values (with standard deviation) of lung function parameters of the $62 \mathrm{RA}$ patients are given in Table II; these values are shown for seropositive and seronegative patients separately, indicating the percentage of patients with abnormal findings. Individual lung function parameters were compared with clinical data and a statistically significant correlation was found between rheumatoid factor and specific $\mathrm{D}_{\mathrm{Lco}}$ only. There were no statistically significant correlations in other parameters. However, a pathological specific compliance was noticed more frequently in patients of Steinbrocker stages 3 and 4 than in those of 1 and 2. A linear relationship, however, did not exist between a decrease of specific compliance and stage of the disease. The group of patients with pathological specific $D_{\text {Lco }}$ showed some increase with Steinbrocker stages, but this was not significant.

The results indicate some correlation between $D_{\text {Lco }}$ and the presence of rheumatoid factor and its titre, respectively. Decreased $D_{\text {Lco }}$ occurred more frequently in seropositive patients $(P<0.05)$, the mean values differing significantly between the two groups $(P<0.025)$. The higher the RF titre the larger the percentage of patients with impaired $D_{L C O}(P<0.01)$. While the relationship between mean $D_{L c o}$ and the four titre groups was not significant, a clear trend can 
Table II Results of lung function study of 62 patients with $R A, 30$ seronegative, 32 seropositive

\begin{tabular}{|c|c|c|c|c|}
\hline & $\begin{array}{l}\text { Total group } \\
(n=62)\end{array}$ & $\begin{array}{l}\text { Seronegative } \\
(n=30)\end{array}$ & $\begin{array}{l}\text { Seropositive } \\
(n=32)\end{array}$ & \\
\hline \multicolumn{5}{|c|}{ VC $(\%$ of nominal value $)(a b<90)$} \\
\hline $\begin{array}{l}\text { Mean } \\
\text { SD } \\
\% \text { abnormal }\end{array}$ & $\begin{array}{l}99 \cdot 29 \\
14 \cdot 43 \\
29\end{array}$ & $\begin{array}{l}98 \cdot 91 \\
17 \cdot 88 \\
30\end{array}$ & $\begin{array}{l}99 \cdot 65 \\
16 \cdot 29 \\
28\end{array}$ & \\
\hline \multicolumn{5}{|c|}{ FRC $(\%$ of TLC) $(a b>62)$} \\
\hline $\begin{array}{l}\text { Mean } \\
\text { SD } \\
\% \text { abnormal }\end{array}$ & $\begin{array}{l}60 \cdot 85 \\
7.47 \\
45\end{array}$ & $\begin{array}{c}59 \cdot 83 \\
7 \cdot 89 \\
43 \cdot 4\end{array}$ & $\begin{array}{c}61 \cdot 82 \\
7 \cdot 13 \\
46 \cdot 8\end{array}$ & \\
\hline \multicolumn{5}{|c|}{ RV $(\%$ of TLC) $(a b>45)$} \\
\hline $\begin{array}{l}\text { Mean } \\
\text { SD } \\
\% \text { abnormal }\end{array}$ & $\begin{array}{l}44 \cdot 08 \\
9 \cdot 50 \\
42\end{array}$ & $\begin{array}{l}41 \cdot 73 \\
12 \cdot 37 \\
46 \cdot 6\end{array}$ & $\begin{array}{c}45 \cdot 32 \\
8 \cdot 84 \\
37 \cdot 5\end{array}$ & \\
\hline \multicolumn{5}{|c|}{$\mathrm{FEV}_{1}(\%$ of $\mathrm{VC})(\mathrm{ab}<70)$} \\
\hline $\begin{array}{l}\text { Mean } \\
\text { SD } \\
\% \text { abnormal }\end{array}$ & $\begin{array}{l}74 \cdot 63 \\
8 \cdot 27 \\
21\end{array}$ & $\begin{array}{l}74 \cdot 94 \\
9 \cdot 17 \\
20\end{array}$ & $\begin{array}{l}74 \cdot 32 \\
7 \cdot 46 \\
21 \cdot 8\end{array}$ & \\
\hline \multicolumn{5}{|l|}{$\mathbf{R}_{\mathrm{aw}}(\mathrm{ab}>3.0)$} \\
\hline $\begin{array}{l}\text { Mean } \\
\text { SD } \\
\% \text { abnormal }\end{array}$ & $\begin{array}{l}2 \cdot 00 \\
1 \cdot 30 \\
17 \cdot 7\end{array}$ & $\begin{array}{l}2 \cdot 30 \\
1 \cdot 56 \\
20\end{array}$ & $\begin{array}{c}1 \cdot 81 \\
0.97 \\
15 \cdot 6\end{array}$ & \\
\hline \multicolumn{5}{|l|}{$\mathrm{C}_{\mathrm{sp}}(\mathrm{ab}<0.055)$} \\
\hline $\begin{array}{l}\text { Mean } \\
\text { SD } \\
\% \text { abnormal }\end{array}$ & $\begin{array}{c}0 \cdot 064 \\
0 \cdot 019 \\
38 \cdot 4\end{array}$ & $\begin{array}{c}0.068 \\
0 \cdot 022 \\
27 \cdot 6 \mathrm{NS}\end{array}$ & $\begin{array}{c}0.061 \\
0 \cdot 016 \\
48 \cdot 4 \mathrm{NS}\end{array}$ & 8 \\
\hline \multicolumn{4}{|l|}{$D_{\mathrm{LCO}}(\mathrm{ab}<4.5)$} & ఫِ \\
\hline $\begin{array}{l}\text { Mean } \\
\text { SD } \\
\% \text { abnormal }\end{array}$ & $\begin{array}{l}5 \cdot 00 \\
1.96 \\
47 \cdot 4\end{array}$ & $\begin{array}{l}5 \cdot 60^{*} \\
2 \cdot 32 \\
31 \dagger\end{array}$ & $\begin{array}{l}4 \cdot 29^{*} \\
1 \cdot 12 \\
64 \cdot 2 \dagger\end{array}$ & 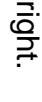 \\
\hline \multicolumn{4}{|c|}{$\mathrm{Po}_{2}(\mathrm{ab}<75,>95)$} & \\
\hline $\begin{array}{l}\text { Mean } \\
\text { SD } \\
\% \text { abnormal }\end{array}$ & $\begin{array}{l}80 \cdot 46 \\
6 \cdot 99 \\
21\end{array}$ & $\begin{array}{l}80 \cdot 96 \\
7 \cdot 46 \\
20\end{array}$ & $\begin{array}{c}80 \cdot 00 \\
6 \cdot 61 \\
21 \cdot 8\end{array}$ & \\
\hline \multicolumn{4}{|c|}{$\mathrm{PCO}_{2}(\mathrm{ab}<35,>45)$} & \\
\hline $\begin{array}{l}\text { Mean } \\
\text { SD } \\
\% \text { abnormal }\end{array}$ & $\begin{array}{c}37 \cdot 25 \\
4 \cdot 28 \\
25 \cdot 8\end{array}$ & $\begin{array}{l}37 \cdot 61 \\
4 \cdot 70 \\
30\end{array}$ & $\begin{array}{c}36 \cdot 92 \\
3 \cdot 89 \\
21 \cdot 8\end{array}$ & \\
\hline
\end{tabular}

* $\mathrm{P}<0.025$ (t-test).

$+\mathrm{P}<0.025(\mathrm{t}-$ test)

VC = vital capacity; $F R C=$ functional residual capacity; $\mathbf{R V}=$ residual volume; $F_{1} V_{1}=$ maximal breathing capacity; $\mathbf{R}_{\mathrm{sw}}=$ airway resistance; $\mathrm{C}=$ specific compliance $; D_{L C O}=$ specific diffusion capacity; $a b=$ abnormal.

be seen (Figure). In addition, seropositive patients more frequently showed a decrease in lung compliance; however, these changes were less extensive than those of diffusion capacity.

\section{Discussion}

Table III shows the results of other authors who found lung function disturbance in patients with RA, expressed in percentage of total material. Our data do not differ from these. Morere and others (1973) observed a triad of impaired $\mathrm{D}_{\mathrm{Lco}}, \mathrm{C}$, and $\mathrm{Po}_{2}$ more frequently in seropositive than in seronegative patients. Less pulmonary dysfunction in seronegative RA was reported by Frank and others (1973); however, titre of rheumatoid factor (RF) did not correlate significantly with normal and pathological

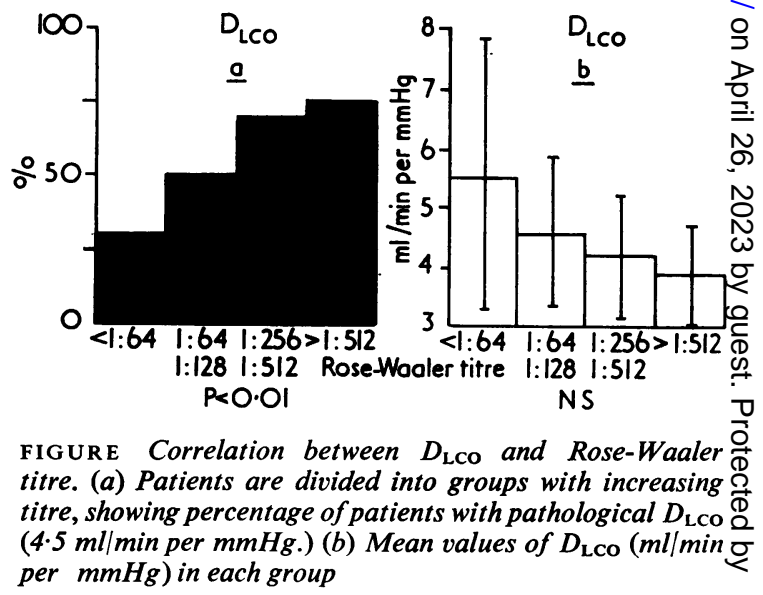


Table III Review of previous reports of lung function in $R A$

\begin{tabular}{|c|c|c|c|}
\hline Author & $\begin{array}{l}D_{\mathrm{LCO}} \\
(\%)\end{array}$ & $\begin{array}{l}\text { Specific compliance } \\
(\%)\end{array}$ & $\begin{array}{l}\text { Vital capacity } \\
(\%)\end{array}$ \\
\hline $\begin{array}{l}\text { Davidson and others (1974) } \\
\text { Frank and others (1973) } \\
\text { Huang and Lyons (1966) } \\
\text { Laitinen and others (1973) } \\
\text { Morere and others (1973) }\end{array}$ & $\begin{array}{l}24 \\
41 \cdot 4 \\
57 \cdot 1 \\
30 \\
55 \cdot 4\end{array}$ & $\begin{array}{l}\overline{-} \\
\bar{z} \\
20 \\
40.5\end{array}$ & $\begin{array}{l}\bar{z} \\
\overline{27} \cdot 2 \\
20 \\
-\end{array}$ \\
\hline
\end{tabular}

$D_{\mathrm{Lco}}$; furthermore, there was no correlation between the frequency of rheumatoid nodules and disturbance of lung function. Popper and others (1972), found no relation between pulmonary dysfunction and RF titre or the presence of rheumatoid nodules. In contrast, our results suggest a significant correlation between $D_{\text {Lco }}$ and RF. Diffusion capacity can be altered by changes at the alveolar membrane, and for other reasons, e.g. by loss of pulmonary capillary volume. The latter can take place also by reduction of perfusion at the arteriolar level, as it occurs in thromboembolic disease and on the basis of inflammatory changes. An increased distending pressure and, therefore, decreased lung compliance has been found mostly in the presence of interstitial changes (congestion, fibrosis etc.). Morphologically, two different types of vascular changes have been reported (Fassbender, 1975) in RA: a nonspecific reaction of the endothelium seen in a variety of inflammatory diseases, being followed by exudation in the surrounding tissue (pneumonitis). This alteration is reversible in the early stage, but may lead to an irreversible fibrosis. Only in seropositive patients might an additional process consisting of necrosis of the arterial wall occur due to autoantibodies or immune-complex deposits. Secondarily, fibroblasts invade the necroses and cellular proliferation of the endothelium occurs. However, these changes have been reported in the vessels of the systemic circulation only; no author refers explicitly to analogous changes in the lesser circulation. A different mechanism has been discussed by Nagaya,
Buckley, and Sieker (1969) who stressed the fact of immune-complex deposits in the alveolar wall of patients with progressive idiopathic interstitial fibrosis.

The decrease of lung compliance found frequently in RA is probably due to inflammatory changes of interstitial tissue, which can develop into interstitial fibrosis. Because interstitial, vascular, and alveolar changes can develop independently of each other and, therefore, may not occur to a similar extent in a given patient, compliance and $D_{\text {Lco }}$ are not necessarily decreased in the same way.

Restriction of lung volumes can be due to pleurisy, increased thoracic rigidity (Huang and Lyons, 1966), and to rheumatoid myopathy. A slight to moderate inspiratory shift of midbreathing level (FRC in \% TLC) and increase in residual volume (in \% TLC) can be due either to the decrease in inspiratory reserve volume, or simply to age-dependent changes of the lung. However, the distribution of these alterations is nearly equal among seropositive and seronegative groups. Bronchial obstruction (as indicated by raised airway resistance and decreased $\mathrm{FEV}_{1}$ ) was found in $17 \cdot 7 \%$. Smoking habits (9 patients, $14.5 \%$ ) should not be neglected entirely when changes in $\mathbf{D}_{\mathrm{Lco}}$ are being reported. However, the distribution of these patients was equal in the respective groups. Lung function changes in RA are certainly of multifactorial origin. Our results indicate an association with rheumatoid factors which may have a role in the pathophysiology of decreased diffusing capacity.

\section{References}

Aronoff, A., Bywaters, E. G. L., And Fearnley, G. R. (1955) Brit. med. J., 2, 228 (Lung lesions in rheumatoid arthritis)

Baldwin, E. De F., Cournand, A., And Richards, D. W., JR. (1948) Medicine, 27, 243 (Pulmonary insufficiency I, physiological classification, clinical methods of analysis standard values in normal subjects)

BöRngen, U. (1975) Z. Rheumatol., 34, 15 (Pulmonary function and rheumatoid arthritis)

Brannan, H. M., Good, C. A., Divertie, M. B., and Baggenstoss, H. H. (1964) J. Amer. med. Ass., 189, 914 (Pulmonary disease associated with rheumatoid arthritis)

Davidson, C., Brooks, A. G. F. AND Bacon, P. A. (1974) Ann. rheum. Dis., 33, 293 (Lung function in rheumatoid arthritis)

FASSBENDER, H. G. (1975) 'Pathology of Rheumatic Diseases'. Springer, Berlin

Frank, S. T., Weg, J. G., Harkleroad, L. E., AND Fitch, R. F. (1973) Chest, 63, 27 (Pulmonary dysfunction in rheumatoid disease)

Georg, J. (1961) Nord. Med., 65, 396 (Pulmonary changes in systemic diseases) 
Hofner, W., LobenWein-Weinegg, E., AND Thumb, N. (1974) Radiologe, 14, 501 (Pulmonary lesions in chronic arthritis and lupus erythematodes disseminatus)

HoRler, A. R., AND ThOMPSON, M. (1959) Ann. intern. Med., 51, 1179 (The pleural and pulmonary complications of rheumatoid arthritis)

HuAng, C. T., AND LyoNs, H. A. (1966) Amer. Rev. resp. Dis., 93, 865 (Comparison of pulmonary function in patients with systemic lupus erythematodes, scleroderma, and rheumatoid arthritis)

Lattinen, O., Salorinne, Y., AND Poppius, H. (1973) Ann. rheum. Dis., 32, 531 (Respiratory function in systemic lupus erythematodes, scleroderma and rheumatoid arthritis)

LoDDenkemper, R., BACH, G. L., AND CARToN, R. W. (1970) Beitr. Klin. Tuberk., 140, 230 (Diffusion defects in rheumatoid arthritis and systemic lupus erythematodes)

Morere, P., Stain, J. P., AND Nouvet, G. (1973) Poumoncoeur, 29, 335 (Respiratory involvement in the course of chronic rheumatoid polyarthritis)

NagaYA, H., BuCKLeY, C. E., AND SieKer, H. O. (1969) Ann. intern. Med., 70, 1135 (Positive antinuclear factor in patients with unexplained pulmonary fibrosis)

Newcomer, A. D., Miller, R. D., Hepper, N. G., ANd CARTer, E. T. (1964) Dis. Chest, 46, 562 (Pulmonary dysfunction in rheumatoid arthritis and systemic lupus erythematodes)

Patterson, C. D., Harville, W. E., AND Pierce, J. A. (1965) Ann. intern. Med., 62, 685 (Rheumatoid lung disease)

PIERCE, J. A. (1968) J. Amer. Geriat. Soc., 16, 514 (Rheumatology and the lungs)

Popper, M. S., BogdonOFF, M. L., AND Hughes, R. L. (1972) Chest, 62, 243 (Interstitial rheumatoid lung disease)

Sievers, K., Hurri, L., AND PertTala, Y. (1964) Acta tuberc. scand., 35, 21 (Studies of rheumatoid pulmonary diseases)

Steinbrocker, O., Traeger, C. H., and Batterman, R. C. (1949) J. Amer. med. Ass., 140, 659 (Therapeutic criteria in rheumatoid arthritis)

TAlbotr, J. A., AND CalKINS, E. (1964) Ibid., 189, 911 (Pulmonary involvement in rheumatoid arthritis)

Tomasi, T. B. JR., FudenberG, H. H., AND FiubY, N. (1962) Amer. J. Med., 33, 243 (Possible relationship of rheumatoid factors and pulmonary disease)

TURNER-WARWICK, M., AND DoNIACH, D. (1965) Brit. med. J., 1, 886 (Auto-antibody studies in interstitial pulmonary fibrosis)

VIGNON, G. (1972) Rev. Rhum., 39, 505 (Pulmonary radiological lesions in 330 cases of rheumatoid arthritis compared with 330 controls)

WALKER, W. C., AND WRIGHT, V. (1969) Ann. rheum. Dis., 28, 252 (Diffuse interstitial pulmonary fibrosis and rheumatoid arthritis)

WARD, R., AND STALKER, R. (1965) Ibid., 24, 246 (Sheep cell agglutination test in chronic interstitial pulmonary fibrosis) 